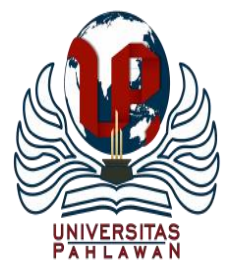

Edukatif : Jurnal Ilmu Pendidikan Volume 3 Nomor 3 Tahun 2021 Halm 794 - 805 EDUKATIF: JURNAL ILMU PENDIDIKAN

Research \& Learning in Education

https:/ledukatif.org/index.php/edukatif/index

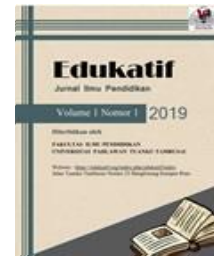

\title{
Peranan Teman Sebaya dan Kebiasaan Belajar terhadap Hasil Belajar Melalui Motivasi Belajar di Masa Covid-19
}

\author{
Puput Agustiningtyas $^{1 凶}$, Jun Surjanti ${ }^{2}$ \\ Program Studi Pendidikan Ekonomi, Universitas Negeri Surabaya, Indonesia ${ }^{1,2}$ \\ E-mail : agustipuput@gmail.com ${ }^{1}$, junsurjanti@ gmail.com ${ }^{2}$
}

\begin{abstract}
Abstrak
Penelitian ini bertujuan mengetahui peranan teman sebaya dan kebiasaan belajar pada masa pandemi covid-19 terhadap hasil belajar ekonomi melalui motivasi belajar. Sampel yang digunakan berjumlah 80 peserta didik kelas XI IPS SMAN 2 Tuban, teknik sampling yang digunakan adalah proportional random sampling. Penelitian ini merupakan penelitian kuantitatif dengan jenis eksplanatori, teknik analisis data yang digunakan adalah SEM-PLS. Temuan penelitian ini diantaranya: (1) Peranan teman sebaya berpengaruh signifikan terhadap motivasi belajar; (2) Kebiasaan belajar berpengaruh signifikan terhadap motivasi belajar; (3) Peranan teman sebaya tidak berpengaruh signifikan terhadap hasil belajar; (4) Kebiasaan belajar berpengaruh signifikan terhadap hasil belajar; (5) Motivasi belajar berpengaruh signifikan terhadap hasil belajar; (6) Tidak terdapat pengaruh signifikan peranan teman sebaya terhadap hasil belajar melalui motivasi belajar; (7) Terdapat pengaruh signifikan kebiasaan belajar terhadap hasil belajar melalui motivasi belajar. Kesimpulannya adalah pada masa pandemi covid-19 motivasi belajar menjadi faktor yang berpengaruh terhadap hasil belajar, dengan fokus kebiasaan belajar dari faktor intrinsik dan dukungan sosial diluar peranan teman sebaya dari faktor ekstrinsik.
\end{abstract}

Kata Kunci: Pandemi Covid-19, Peranan teman sebaya, Kebiasaan belajar, Motivasi Belajar, Hasil belajar.

\begin{abstract}
This study aims to determine the role of peers and habits of learning during the Covid-19 pandemic on economic learning results through learning motivation. The samples were 80 students of eleventh graders of social studies in SMAN 2 Tuban. The sampling technique used was proportional random sampling. This approach used in this study was an explanatory quantitative. Furthermore, the analysis technique used was SEM-PLS. The results showed that: (1) The role of peers had significant effect on learning motivation; (2) The learning habits had significantly affect the learning motivation; (3) The role of peers did not have significant effect on learning results; (4) The learning habits had significantly affect the learning results; (5) The learning motivation had significantly affect the learning results; (6) There was no significant influence of peers' role to learning results through learning motivation; (7) There were significant effect of learning habits toward the learning results through learning motivation. In conclusion, in the Covid-19 pandemic era, the learning motivation become an influential factor in learning results, by focusing in the learning as the intrinsic factors and the social supports outside the role of peers as the extrinsic factors.
\end{abstract}

Keywords: Pandemic of Covid-19, role of peer, study habits, learning motivation, study outcomes.

Copyright (c) 2021 Puput Agustiningtyas, Jun Surjanti

$\triangle$ Corresponding author

Email : agustipuput@gmail.com

DOI : https://doi.org/10.31004/edukatif.v3i3.454

ISSN 2656-8063 (Media Cetak)

ISSN 2656-8071 (Media Online)

Edukatif : Jurnal Ilmu Pendidikan Vol 3 No 3 Tahun 2021

p-ISSN 2656-8063 e-ISSN 2656-8071 


\section{PENDAHULUAN}

Pandemi Covid-19 yang melanda dunia telah mengubah tatanan kehidupan masyarakat, termasuk Indonesia (Puspensos, 2020). Pandemi ini berdampak pada berberbagai bidang termasuk pendidikan. Covid19 membuat sistem pendidikan di Indonesia mengalami metamorfosis. Dalam rangka mencegah penyebaran dan penularan virus ini, tanggal 24 Maret 2020 pemerintah melalui Menteri Pendidikan dan Kebudayaan (2020) mengeluarkan Surat Edaran Nomor 4 Tahun 2020 yang mengatur Pelaksanaan Kebijakan Pendidikan di Masa Darurat Covid-19. Surat Edaran tersebut menginstruksikan proses pembelajaran dilakukan dari rumah dengan sistem daring. Dengan diberlakukannya surat edaran ini menyebabkan peserta didik tidak dapat berinteraksi dengan teman ataupun guru secara tatap muka. Menurut riset yang dilakukan oleh PW IPM DIY menunjukkan bahwa pembelajaran dari membuat $63 \%$ responden sulit memahami materi pelajaran atau perkuliahan dan sebanyak 35,1\% responden berpendapat belajar dari rumah dirasa kurang efektif (Alyaum, 2020). Beberapa faktor yang memengaruhi adalah sulitnya akses jaringan, dan minimnya interaksi antar peserta didik maupun peserta didik dengan pengajar. Ketidakefektifan metode pembelajaran berbasis daring ini akan berdampak pada kurang maksimalnya hasil belajar yang diperoleh.

Suprijono (2014) mendefinisikan hasil belajar sebagai pola, perbuatan, nilai, pengertian, sikap serta keterampilan setalah mendapatkan serangkaian pengalaman belajar. Dalam penelitian (Hartini 2020) mengungkapkan bahwa pembelajaran daring membuat hasil belajar peserta didik meningkat. Namun keadaan dilapangan menunjukkan bahwa peserta didik SMA Negeri 2 Tuban di kelas XI IPS hanya memperoleh ratarata nilai ekonomi sebesar 54,44 dari KKM yang ditetapkan 70 . Salah satu sebab yang memengaruhi rendahnya hasil belajar yakni adanya penurunan motivasi untuk belajar, hal ini serupa dengan hasil penelitian (Cahyani, Listiana, and Larasati 2020) yang menyebutkan bahwa pembelajaran daring ditengah situasi pandemi covid 19 membuat motivasi belajar peserta didik menurun. Menurut Sardiman (2012) motivasi adalah suatu daya yang memberikan dorongan perilaku untuk mencapai tujuan. Sejalan dengan penelitian dari (Guay et al., 2010) yang motivasi adalah alasan yang mendasari perilaku. Temuan di lapangan menurut hasil wawancara dengan guru pengampu ekonomi di SMAN 2 Tuban diketahui pembelajaran berbasis daring membuat atmosfer pembelajaran disetiap kelas berbeda. Temuan di lapangan menunjukkan terdapat kelas yang dominan aktif dan pasif. Beliau menjelaskan bahwa di kelas yang aktif, lebih dari $50 \%$ peserta didik berebut untuk menjawab. Dari data tersebut diketahui bahwa, rasa ingin berkompetisi membuat individu menganggap teman sebayanya sebagai kompetitor. Sedangkan, kelas yang dominan pasif disebabkan karena rendahnya rasa semangat berkompetisi dalam belajar. Terdapat masalah lain yakni, bahwa $70 \%$ hasil kerja peserta didik antara satu dengan yang lain sama, sehingga diindikasikan dalam pengerjaannya sebagian peserta didik saling menyontek. Kondisi ini bertentangan dengan hasil riset (Bakar, 2014) dimana motivasi belajar tercermin dari pengerjaan tugas, waktu dan tenaga yang mereka curahkan, ketekunan dalam mengerjakan tugas dan mengatasi kendala yang dihadapi dalam proses belajar. Situasi dilapangan juga bertentangan dengan penelitian (Fitriyani, Fauzi, and Sari 2020) yang menyebutkan bahwa motivasi belajar peserta didik di masa pandemi covid-19 cenderung tinggi. (Dörnyei and Ushioda, 2013) mengungkapkan bahwa kelompok sebaya memberikan pengaruh kuat pada motivasi individu, terutama dikalangan pelajar remaja.

Menurut (Wilson 2016) peserta didik yang memiliki rekan yang mampu mencapai hasil belajar lebih tinggi maka akan cenderung mempengaruhi peningkatan kinerja akademis bagi individu lain dalam kelompok. (Santrock 2011) mengemukakan kumpulan teman sebaya dapat berpengaruh positif ataupun negatif tergantung pada tujuannya. Apabila kumpulan teman sebayanya memiliki performa kinerja tinggi maka hal itu akan mendorong peningkatan kecakapan bagi individu lain, dan berlaku sebaliknya. Pemilihan subjek penelitian di XI didasarkan pada penelitian (Novandhika 2017) yang mengungkapkan di kelas XI peserta didik mulai berhubungan yang lebih erat dan mulai membuat kumpulan teman bermain setelah sebelumnya pada 
kelas X mereka beradaptasi dengan lingkungan baru di masa SMP. Menurut pernyataan guru pengampu ekonomi, hanya terdapat 1 kelas yang peserta didiknya aktif saat pembelajaran dan memperoleh nilai diatas kriteria ketuntasan, kondisi dimana peserta didik memiliki teman yang aktif dalam proses pembelajaran dan mendapat hasil belajar tinggi, maka akan berpengaruh pada diri peserta didik tersebut untuk dapat menyamai pencapaian temannya yang lain. Kondisi ini bertolak belakang dengan 2 kelas lain, para peserta didiknya pasif dan memperoleh nilai dibawah Kriteria Ketuntasan. Berdasarkan penelitian (Hassan et al. 2018) diketahui bahwa kompetisi selama masa studi adalah salah satu faktor yang memengaruhi perilaku belajar individu.

Menurut (Hassan et al. 2018) kebiasaan belajar adalah praktek belajar yang meliputi frekuensi belajar dengan duduk, latihan materi yang dipelajari, review materi belajar di lingkungan yang menguntungkan dan ujian mandiri. (Salcedo-Relucio 2019) mengungkapkan kebiasaan belajar berperan penting, dan berpengaruh pada keberhasilan belajar. Menurut (Rabia et al. 2017) kebiasaan belajar adalah cara seseorang untuk fokus dan menghabiskan waktu dalam belajar. Dalam penelitiannya (Fouché 2017) menggambarkan kebiasaan belajar yang baik seperti mengerjakan pekerjaan rumah, berpartisipasi aktif di kelas, mengatur waktu, tetap fokus dan bekerja keras menunjukkan korelasi positif terhadap hasil belajar akademik. Itulah sebabnya kebiasaan yang baik merupakan prasyarat untuk hasil belajar yang baik (Salcedo-Relucio, 2019). Sedangkan berdasarkan data temuan di lapangan, 12 dari 19 peserta didik yang ditemui peneliti mengungkapkan bahwa mereka tidak memiliki jadwal belajar yang tetap dan menghabiskan lebih banyak waktu untuk bermain daripada belajar selama masa pandemi ini. Hal ini serupa dengan riset yang dilakukan (Jatira and Neviyarni, 2021) yang menyatakan pada masa pandemi covid-19 peserta didik menjadi bosan dan malas belajar dikarenakan beberapa gangguan yang mungkin terjadi dalam pembiasaan pembelajaran daring.

Berdasarkan penelitian terdahulu yang dilakukan Dörnyei and Ushioda (2013) mengemukakan bahwa teman sebaya memberikan pengaruh kuat terhadap motivasi belajar terutama dikalangan remaja. Motivasi ini yang berfungsi sebagai roda penggerak suatu aktifitas, dalam hal ini yang dimaksud adalah kegiatan belajar. Motivasi yang tinggi akan berpengaruh terhadap perolehan hasil belajar peserta didik sesuai dengan penelitian (Sholihah and Kurniawan 2016). Kebiasaan belajar merupakan suatu hal yang perlu diperhatikan terutama pada masa pembelajaran daring, peserta didik yang berkebiasaan belajar baik merupakan cerminan dari motivasi belajar yang baik, hal ini sejalan dengan penelitian yang dilakukan (Hasanah, Abdurakhman, and Ichsan 2016). Dan lagi, tingginya motivasi untuk belajar akan berpengaruh terhadap hasil belajar peserta didik. Berdasarkan penelitian-penelitian yang telah dipaparkan, maka penelitian ini bertujuan untuk meneliti peranan apakah teman sebaya dan kebiasaan belajar berpengaruh secara langsung/tidak langsung terhadap hasil belajar. Yang membedakan penelitian ini dengan penelitian terdahulu adalah motivasi belajar menempati posisi variabel intervening, bukan variabel dependen. Mengingat motivasi adalah kunci dari keberhasilan belajar terutama pada masa pandemi covid-19 yang mana pembelajaran dilaksanakan secara daring dan tanpa kontrol dari seorang guru, sehingga motivasi menjadi faktor intern yang diperlukan.

Berdasarkan penjabaran diatas, peneliti akan melakukan penelitian "Pengaruh Peranan Teman Sebaya dan Kebiasaan Belajar pada Masa Pandemi Covid-19 terhadap Hasil Belajar Melalui Motivasi Belajar Sebagai Variabel Intervening (Studi Pada Peserta didik Kelas XI IPS SMAN 2 Tuban)”.

\section{METODE}

Pendekatan yang digunakan dalam penelitian ini adalah kuantitatif, dengan jenis eksplanatori. Total popolasi sebanyak 105 peserta didik kelas XI IPS SMA Negeri 2 Tuban. Sampel yang digunakan sebanyak 80 peserta didik, Pemilihan sampel berdasarkan Tabel Sampel Krejcie dan Morgan dengan teknik sampling proportional random sampling. 
797 Peranan Teman Sebaya dan Kebiasaan Belajar terhadap Hasil Belajar Melalui Motivasi Belajar di Masa Covid-19 - Puput Agustiningtyas, Jun Surjanti

DOI: https://doi.org/10.31004/edukatif.v3i3.454

Penelitian ini bertujuan mengetahui pengaruh antara variabel independen yaitu Peranan Teman Sebaya (X1) dan Kebiasaan Belajar (X2) melalui variabel intervening yaitu motivasi belajar (Y1) terhadap variabel dependen yaitu Hasil Belajar (Y2).

Riset ini menggunakan data primer dan data sekunder. Sumber data Primer didapatkan dari kuesioner tertutup peranan teman sebaya, kebiasaan belajar dan motivasi belajar. Skala Likert digunakan sebagai skala pengukuran kuesioner dengan pilihan Sangat tidak setuju (1) hingga sangat setuju (4). Sedangkan untuk sumber data sekunder menggunakan dokumentasi nilai ekonomi PAS Ganjil peserta didik yang didapatkan dari guru.

\section{HASIL DAN PEMBAHASAN}

Pada perhitungan Convergent validity and Reliability diketahui bahwa seluruh indikator dapat dikatakan signifikan dilihat dari nilai faktor loading $>0,30$ dan nilai p-value $<0,05$ dan Koefisien Composite Reliability (CR) menunjukkan angka >0,70. Maka dapat disimpulkan bahwa semua nilai Reliabilitas Komposit terpenuhi. Fungsi dari validitas konvergen adalah menguji korelasi antara skor indikator reflektif satu dengan yang lain pada baris yang sama guna menimbang nilai konstruk (Ghozali and Latan, 2014).

Tabel 1. Convergent validity and Reliability

\begin{tabular}{|c|c|c|c|}
\hline Item & Loading & p-value & CR \\
\hline Standar Nilai & $\mathbf{> 0 , 3 0}$ & $<\mathbf{0 , 0 5}$ & $\mathbf{> 0 , 7 0}$ \\
\hline PTS & & & 0,88 \\
\hline X1.1 & 0,44 & $<0.001$ & \\
\hline X1.2 & 0,57 & $<0.001$ & \\
\hline X1.3 & 0,54 & $<0.001$ & \\
\hline X1.4 & 0,58 & $<0.001$ & \\
\hline X1.5 & 0,56 & $<0.001$ & \\
\hline KB & & & \\
\hline X2.1 & 0,59 & $<0.001$ & \\
\hline X2.2 & 0,52 & $<0.001$ & \\
\hline X2.3 & 0,54 & $<0.001$ & \\
\hline X2.4 & 0,50 & $<0.001$ & \\
\hline X2.5 & 0,51 & $<0.001$ & \\
\hline X2.6 & 0,47 & $<0.001$ & \\
\hline MB & & & \\
\hline Y1.1 & 0,76 & $<0.001$ & \\
\hline Y1.2 & 0,78 & $<0.001$ & \\
\hline Y1.3 & 0,85 & $<0.001$ & \\
\hline Y1.4 & 0,71 & $<0.001$ & \\
\hline Y1.5 & 0,68 & $<0.001$ & \\
\hline Y1 6 & 0,74 & $<0.001$ & \\
\hline Y1.7 & 0,77 & $<0.001$ & \\
\hline HS & & & \\
\hline Y2 & 1,00 & $<0.001$ & \\
\hline & & & \\
\hline
\end{tabular}


Pada perhitungan Discriminant validity komponen yang digunakan diantaranya koefisien cross loading dan Average Variance Extracted (AVE). Berdasarkan Tabel 2, dapat diketahui bahwa syarat untuk dapat dikatakan valid adalah setiap indikator memiliki nilai cross loading > konstruknya. Nilai AVE dinyatakan valid jika setiap konstruk > dibanding koefisien korelasi antar konstruk pada baris yang sama. Pada penelitian ini, nilai AVE terdapat konstruk yang lebih kecil dari nilai korelasi antar konstruk yakni pada variabel Kebiasaan Belajar. Maka, dapat diartikan bahwa syarat validitas diskriminan pada tiga variabel terpenuhi dan satu variabel tidak terpenuhi yakni pada variabel kebiasaan belajar.

Tabel 2. Nilai Cross Loading

\begin{tabular}{|c|c|c|c|c|}
\hline Indikator & PTS & KB & MB & HB \\
\hline $\mathrm{X} 1.1$ & $(0.636)$ & 0.001 & 0.002 & 0.427 \\
\hline $\mathrm{X} 1.2$ & $(0.826)$ & -0.013 & -0.111 & 0.088 \\
\hline $\mathrm{X} 1.3$ & $(0.773)$ & -0.002 & 0.060 & -0.107 \\
\hline $\mathrm{X} 1.4$ & $(0.832)$ & 0.122 & -0.051 & -0.032 \\
\hline $\mathrm{X} 1.5$ & $(\mathbf{0 . 8 1 0})$ & -0.111 & 0,106 & -0.290 \\
\hline $\mathrm{X} 2.1$ & 0,115 & $(0.844)$ & -0.113 & 0,116 \\
\hline $\mathrm{X} 2.2$ & -0.007 & $(0.746)$ & -0.148 & -0.297 \\
\hline $\mathrm{X} 2.3$ & -0.124 & $(0.777)$ & -0.257 & 0.086 \\
\hline $\mathrm{X} 2.4$ & 0.079 & $(0.718)$ & 0.555 & 0.070 \\
\hline $\mathrm{X} 2.5$ & 0.004 & $(0.733)$ & -0.146 & 0,113 \\
\hline $\mathrm{X} 2.6$ & 0.082 & $(0.680)$ & 0,168 & -0.113 \\
\hline Y1.1 & 0,148 & 0.091 & $(0.763)$ & -0.141 \\
\hline Y1.2 & -0.045 & -0.227 & $(0.782)$ & -0.201 \\
\hline Y1.3 & 0,149 & -0.139 & $(0.851)$ & 0.031 \\
\hline Y1.4 & 0,182 & -0.038 & $(0.715)$ & -0.079 \\
\hline Y1.5 & 0.094 & -0.047 & $(0.686)$ & -0.115 \\
\hline Y1.6 & -0.300 & 0,266 & $(0.742)$ & 0,240 \\
\hline Y1.7 & -0.227 & 0,114 & $(0.774)$ & 0,157 \\
\hline
\end{tabular}

Tabel 3. Square Root of AVE

\begin{tabular}{|l|c|c|c|c|}
\hline & PTS & KB & MB & HB \\
\hline PTS & $\mathbf{( 0 , 7 7 9 )}$ & 0,521 & 0,562 & 0,462 \\
\hline KB & 0,521 & $\mathbf{( 0 , 7 5 2})$ & 0,755 & 0,609 \\
\hline MB & 0,562 & 0,755 & $\mathbf{( 0 , 7 6 0 )}$ & 0,655 \\
\hline HB & 0,462 & 0,609 & 0,655 & $\mathbf{( 1 , 0 0 0 )}$ \\
\hline
\end{tabular}

Pada perhitungan Goodness of Fit Model diketahui secara keseluruhan model penelitian mempunyai fit yang baik dan layak, berdasarkan koefisien p-value dari Average Path Coefficient, Average R-squared, Average Adjusted $R$ - squared $<0,05$. Nilai dari Average Path Coefficient $=0,334 ;$ Average $R$-squared $=0,563$; Average Adjusted $R$ - squared $=0,549$. Koefisien dari AVIF dan AFVIF pada penelitian ini $<3,3$ artinya bebas dari masalah pada multikolinieritas antar indikator serta antar variabel. Indeks Sympson's Paradox Ratio; $R$ squared Contribution Ratio; Statistical Suppression Ratio; dan Nonlinear Bivariate Causality Direction Ratio juga menunjukkan ukuran yang fit, artinya pada model penelitian ini tidak ada masalah kausalitas. 
Tabel 4. Evaluasi Goodness of Fit Model

\begin{tabular}{|c|c|c|c|}
\hline GoF & Kriteria & Hasil & Ket. \\
\hline APC & $\mathrm{p}<0,05$ & $0,334(\mathrm{P}<0,001)$ & Terpenuhi \\
\hline ARS & $\mathrm{p}<0,05$ & $0,563(\mathrm{P}<0,001)$ & Terpenuhi \\
\hline AARS & $\mathrm{p}<0,05$ & $0,549(\mathrm{P}<0,001)$ & Terpenuhi \\
\hline AVIF & $\leq 3,3$ & 1,884 & Terpenuhi \\
\hline AFVIF & $\leq 3,3$ & 2,199 & Terpenuhi \\
\hline \multirow{2}{*}{ GoF } & Small $\geq 0,1$ & & \\
\cline { 2 - 2 } & Medium $\geq 0,25$ & 0,622 & Large \\
\cline { 2 - 4 } & Large $\geq 0,36$ & & Terpenuhi \\
\hline SPR & $=1$ & 1,000 & Terpenuhi \\
\hline RSCR & $=1$ & 1,000 & Terpenuhi \\
\hline SSR & $\geq 0,7$ & 1,000 & Terpenuhi \\
\hline NLBCDR & $\geq 0,7$ & 1,000 & \\
\hline
\end{tabular}

Terdapat dua komponen yang digunakan untuk melihat Hasil Pengujian Hipotesis yakni Pengaruh langsung dan pengaruh tidak langsung. Dimana pada penelitian ini peroleh hasil sebagai berikut:

Tabel 5. Pengaruh Langsung

\begin{tabular}{|c|c|c|c|c|c|}
\hline No & \multicolumn{2}{|c|}{$\begin{array}{c}\text { Hubungan Antar } \\
\text { Variabel }\end{array}$} & $\begin{array}{c}\text { Koefisien } \\
\text { Jalur }\end{array}$ & P-Value & Keterangan \\
\hline 1 & $\mathrm{X} 1$ & $\mathrm{Y} 1$ & 0,276 & 0,003 & Signifikan \\
\hline 2 & $\mathrm{X} 2$ & $\mathrm{Y} 1$ & 0,612 & $<0,001$ & Signifikan \\
\hline 3 & $\mathrm{X} 1$ & $\mathrm{Y} 2$ & 0,104 & 0,17 & Tidak Signifikan \\
\hline 4 & $\mathrm{X} 2$ & $\mathrm{Y} 2$ & 0,296 & 0,002 & Signifikan \\
\hline 5 & $\mathrm{Y} 1$ & $\mathrm{Y} 2$ & 0,381 & $<0,001$ & Signifikan \\
\hline
\end{tabular}

Tabel 6. Pengaruh Tidak Langsung

\begin{tabular}{|c|c|c|c|c|c|c|}
\hline No & $\begin{array}{c}\text { Variabel } \\
\text { Penjelas }\end{array}$ & $\begin{array}{c}\text { Variabel } \\
\text { Intervening }\end{array}$ & $\begin{array}{c}\text { Variabel } \\
\text { Respon }\end{array}$ & $\begin{array}{c}\text { Koefisien } \\
\text { Jalur } \\
\text { Pengaruh } \\
\text { Tidak } \\
\text { Langsung }\end{array}$ & $\begin{array}{c}\text { P } \\
\text { Value }\end{array}$ & Ket \\
\hline 1 & $\begin{array}{c}\text { Peranan } \\
\text { Teman } \\
\text { Sebaya } \\
(X 1)\end{array}$ & $\begin{array}{c}\text { Motivasi } \\
\text { Belajar (Y1) }\end{array}$ & $\begin{array}{c}\text { Hasil } \\
\text { belajar } \\
\text { (Y2) }\end{array}$ & 0,105 & 0.087 & $\begin{array}{c}\text { Tidak } \\
\text { Interveni } \\
\text { ng }\end{array}$ \\
\hline 2 & $\begin{array}{c}\text { Kebiasaan } \\
\text { Belajar } \\
\text { (X2) }\end{array}$ & $\begin{array}{c}\text { Motivasi } \\
\text { Belajar (Y1) }\end{array}$ & $\begin{array}{c}\text { Hasil } \\
\text { Belajar } \\
\text { Ely2 }\end{array}$ & 0,233 & 0.001 & $\begin{array}{c}\text { Interveni } \\
\text { ng }\end{array}$ \\
\hline
\end{tabular}

(X2) 


\section{Pengaruh Peranan Teman Sebaya pada masa pandemi covid-19 terhadap Motivasi Belajar}

Berdasarkan hasil pengujian hipotesis didapatkan hasil bahwa pengaruh teman sebaya (X1) pada pandemi covid 19 terhadap motivasi belajar (Y1) memiliki koefisien jalur sebesar 0,235 dan $P$ Value 0,013. Mengingat koefisien $p$-value $<0,05$ oleh karenanya dikatakan signifikan, sehingga hipotesis tersebut diterima. Koefisien jalur bertanda positif $(0,235)$ artinya terdapat pengaruh positif antara Peranan Teman Sebaya terhadap Motivasi Belajar di masa pandemi covid-19.

Data empiris di lapangan menunjukkan bahwa peserta didik yang memiliki teman sebaya dengan semangat belajar tinggi atau dapat dikatakan termotivasi dalam belajar akan memengaruhi peserta didik lainnya untuk dapat menyamai semangat belajar temannya. Begitu pula sebaliknya, apabila seorang peserta didik memiliki teman sebaya yang kurang termotivasi belajar akan membuat individu tersebut malas dalam belajar. Walaupun pembelajaran dilaksanakan secara daring namun peserta didik tetap melaksanakan diskusi online dan saling mengingatkan untuk mengerjakan tugas. Pembelajaran online tidak menyurutkan semangat untuk saling berlomba dalam mendapatkan nilai terbaik pada mata pelajaran ekonomi. Hal ini mengindikasikan bahwa peranan teman sebaya pada masa pandemi turut berperan dalam meningkatkan motivasi dalam belajar.

Hal tersebut diperkuat dengan teori yang menyebutkan teman sebaya adalah salah satu aspek penting yang memengaruhi motivasi belajar terutama dikalangan pelajar remaja (Dörnyei and Ushioda 2013). Hal tersebut membuat pentingnya menjaga iklim pertemanan yang menjunjung tinggi semangat berkompetisi dalam pembelajaran, agar antar peserta didik saling termotivasi.

Dengan demikian, meski dalam kondisi pandemi covid-19 dengan pembelajaran dilakukan secara daring seorang pelajar yang memiliki teman sebaya dengan motivasi belajar tinggi akan membuat ia ikut termotivasi untuk melakukan hal yang sama dalam pembelajaran. Maka, dapat diketahui bahwa motivasi belajar peserta didik kelas XI IPS di SMAN 2 Tuban dipengaruhi oleh peranan teman sebaya.

\section{Pengaruh kebiasaan belajar pada masa pandemi covid-19 terhadap motivasi belajar}

Berdasarkan pengujian hipotesis didapatkan bahwa Pengaruh Kebiasaan Belajar (X2) di masa pandemi covid-19 terhadap Motivasi Belajar (Y1) diperoleh koefisien jalur sebesar 0,643 dan $P$ Value sebesar $<0,001$ yang artinya $P$ Value $<0,05$ maka dari itu dikatakan signifikan atau dapat diartikan bahwa kebiasaan belajar di masa covid-19 berpengaruh terhadap motivasi belajar. Koefisien jalur bertanda positif $(0,643)$ mengindikasikan terdapat pengaruh positif antara kebiasaan belajar terhadap Motivasi Belajar pada masa pandemi covid-19.

Data empiris di lapangan menunjukkan bahwa kebiasaan belajar yang baik akan membuat semakin tinggi motivasi belajar ekonomi bagi kelas XI IPS. Walaupun pembelajaran dilaksanakan secara daring namun peserta didik tetap memiliki durasi waktu tertentu untuk belajar dan mengerjakan tugas setiap harinya, tetap mencatat penjelasan atau materi yang diberikan oleh guru, menyelesaikan tugas dengan bersungguh-sungguh dan tidak segan bertanya saat menemui kesulitan dalam belajar. Hal tersebut merupakan indikasi bahwa pembelajaran daring tidak mengurangi motivasi belajar dan peserta didik tetap berkebiasaan belajar yang baik.

Temuan ini sejalan dengan riset dari (Hasanah et al. 2016) dimana kebiasaan belajar berpengaruh pada motivasi belajar. Peserta didik yang memiliki kebiasaan belajar baik akan berpengaruh pada motivasi belajar karena ketika seorang peserta didik merasa jika dirinya kurang termotivasi dalam belajar maka indikasi untuk mengukur adalah kebiasaan yang dilakukan guna merealisasikan motivasi tersebut.

Dengan demikian, meski dalam kondisi pandemi covid-19 dengan pembelajaran yang dilakukan secara daring seorang pelajar yang memiliki kebiasaan belajar baik maka semakin baik motivasi belajarnya. Maka, dapat dikatahui bahwa pada kelas XI IPS di SMAN 2 Tuban Kebiasaan Belajar memengaruhi Motivasi Belajar. 
801 Peranan Teman Sebaya dan Kebiasaan Belajar terhadap Hasil Belajar Melalui Motivasi Belajar di Masa Covid-19 - Puput Agustiningtyas, Jun Surjanti

DOI: https://doi.org/10.31004/edukatif.v3i3.454

\section{Peranan Teman Sebaya pada masa pandemi covid-19 berpengaruh terhadap Hasil Belajar}

Berdasarkan hasil pengujian hipotesis didapat hasil bahwa peranan teman sebaya (X1) di masa pandemi covid-19 terhadap hasil belajar (Y2) memiliki koefisien jalur sebesar 0,082 dan $P$ Value 0,226 yang artinya $P$ Value $>$ 0,05 maka dari itu dikatakan tidak signifikan atau dapat diartikan bahwa peranan teman sebaya di masa pandemi covid-19 tidak berpengaruh terhadap hasil belajar ekonomi peserta didik XI IPS sehingga hipotesis ditolak.

Belajar dari rumah menyebabkan peserta didik tidak dapat berinteraksi secara langsung baik dengan teman sebayanya ataupun dengan guru. Hal ini membuat proses transfer ilmu tidak berjalan dengan maksimal karena terdapat gangguan baik jariangan ataupun suasana rumah yang kurang kondusif, sehingga berakibat pada rendahnya pemahaman materi dan bermuara pada rendahnya hasil belajar. Hasil ini sejalan dengan Riset (Alyaum 2020) yang menyebutkan bahwa 63\% responden baik siswa ataupun mahasiswa merasa sulit memahami pelajaran atau mata kuliah pada saat pembelajaran daring. Sejalan pula dengan penelitian yang dilakukan oleh (Lestari, Ma'wiyah, and Ihsan 2020) yang menyatakan bahwa teman bergaul tidak berpengaruh pada IPK. Dengan demikian penelitian ini membantah penelitian dari (Wilson 2016) yang menyatakan peserta didik dengan teman yang mampu melampaui hasil belajar lebih tinggi akan cenderung memengaruhi peningkatan kinerjanya.

Dengan demikian, dalam kondisi pandemi covid-19 dengan pembelajaran yang dilakukan secara daring peranan teman sebaya pada peserta didik kelas XI IPS SMA Negeri 2 Tuban tidak berpengaruh langsung pada hasil belajar.

\section{Pengaruh Kebiasaan Belajar pada Masa Pandemi Covid-19 Berpengaruh terhadap Hasil Belajar}

Berdasarkan hasil pengujian hipotesis didapatkan hasil bahwa Pengaruh Kebiasaan Belajar (X2) di masa pandemi covid-19 terhadap Hasil belajar (Y2) memiliki koefisien jalur sebesar 0,331 dan $P$ Value $<0,001$ yang artinya $P$ Value $<0.05$ maka dari itu dikatakan signifikan atau dapat diartikan bahwa Kebiasaan Belajar pada masa pandemi covid-19 berpengaruh signifikan terhadap hasil belajar ekonomi pada peserta didik XI IPS. Koefisien jalur bertanda positif $(0,331)$ menandakan Kebiasaan Belajar berpengaruh positif terhadap Hasil Belajar di masa pandemi covid-19.

"Belajar dari rumah" menggunakan sistem daring merupakan perwujudan solusi ditengah pandemi covid-19 bagi dunia pendidikan. Tanpa adanya kontrol dari guru ataupun pihak sekolah, peserta didik diharapkan berkebiasaan belajar yang baik. Temuan penelitian ini, tingginya hasil belajar ekonomi dipengaruhi oleh kebiasaan belajar yang baik dari peserta didik kelas XI IPS.

Didukung oleh penelitian dari (Chamundeswari, Sridevi, and Kumari 2014) yang mengemukakan bahwa rendahnya hasil belajar adalah akibat dari kebiasaan belajar yang buruk. Atau dapat diartikan pula apabila seorang peserta didik menunjukkan kebiasaan belajar yang kurang baik (contohnya sulit berkonsentrasi penuh, cepat merasa bosan, letih serta mengantuk dikala proses pembelajaran, tidak memiliki tujuan yang ingin dicapai pada pembelajaran dan lebih banyak waktu yang diluangkan untuk bermain) terdapat kemungkinan bahwa peserta didik tersebut rendahnya motivasi dalam mengikuti pembelajaran.

Dengan demikian, meski dalam kondisi pandemi covid-19 dengan pembelajaran yang dilakukan secara daring seorang pelajar dengan kebiasaan belajar yang baik akan mendapatkan hasil belajar yang tinggi. Maka, dapat diketahui bahwa pada kelas XI IPS di SMAN 2 Tuban Kebiasaan belajar peserta didik berpengaruh pada hasil belajar yang diperoleh.

\section{Pengaruh Motivasi Belajar Peserta Didik pada Masa Pandemi Covid-9 terhadap Hasil Belajar}

Hasil yang diperoleh dari pengujian hipotesis Pengaruh Motivasi Belajar (Y1) di masa pandemi covid19 terhadap Hasil belajar (Y2) menunjukkan koefisien jalur 0,375 dan $P$ Value $<0,001$. Hipotesis tersebut diterima, mengingat $P$ Value $<0,05$. Artinya Motivasi Belajar di masa pandemi covid-19 berpengaruh pada 
hasil belajar ekonomi kelas XI IPS. Koefisien jalur bertanda positif $(0,375)$ mengindikasikan terdapat korelasi positif antara Motivasi Belajar terhadap Hasil Belajar pada masa pandemi.

Motivasi yang tinggi untuk belajar diperlukan khususnya pada masa pandemi, pembelajaran yang dilaksanakan secara daring membuat lemahnya pengawasan guru, guru tidak dapat mengontrol kegiatan belajar peserta didik secara langsung, oleh karenanya motivasi sangat diperlukan, tanpa motivasi peserta didik akan merasa kurang bersemangat dalam belajar. Secara statistik pada penelitian ini menunjukkan bahwa tingkat motivasi belajar berbanding lurus dengan hasil belajarnya. Serupa dengan hasil riset yang dilakukan (Pratama, Firman, and Neviyarni 2019; Sartika, Dahlan, and Waspada 2018) dimana hasil belajar ekonomi dipengaruhi oleh motivasi belajar. Diperkuat dengan pendapat (Sardiman 2012) bahwa motivasi belajar yang tepat akan membuat optimalnya hasil belajar.

Dengan demikian, dalam kondisi pandemi covid-19 dengan pembelajaran yang dilakukan secara daring motivasi untuk belajar pada peserta didik kelas XI IPS di SMAN 2 Tuban berpengaruh terhadap hasil belajar yang diperoleh.

\section{Pengaruh Peranan Teman Sebaya pada Masa Pandemi Covid-19 terhadap Hasil Belajar Ekonomi dengan Motivasi Belajar sebagai Variabel Intervening}

Temuan yang diperoleh dari pengujian hipotesis peranan teman sebaya di masa covid-19 terhadap hasil belajar ekonomi melalui motivasi belajar memiliki koefisien jalur sebesar 0,088 dan $p$-value 0,127 . Mengingat p-value $>0,05$ maka dapat dikatakan tidak signifikan, jadi dapat disimpulkan motivasi belajar tidak dapat menjadi variabel intervening peranan teman sebaya terhadap hasil belajar sehingga hipotesis ditolak.

Teman sebaya merupakan faktor eksternal, sedangkan kebiasaan belajar adalah faktor internal yang berpengaruh pada hasil belajar. Mengingat hasil penelitian (Wilson 2016) menyatakan bahwa kinerja akademik kelompok sebaya cenderung menarik setiap anggota kelompok sebaya untuk memiliki tingkat kinerja akademik yang sama dengan kelompoknya. Menurut (Dörnyei and Ushioda 2013) teman sebaya berpengaruh terhadap motivasi belajar. Didukung oleh penelitian Menurut (Agustina and Kurniawan 2020) yang menyatakan di masa pandemi covid-19 dukungan sosial dan konsep diri adalah aspek yang berpengaruh terhadap motivasi belajar. Dukungan sosial utama yang berperan menumbuhkan motivasi belajar di masa pandemi berasal dari lingkungan keluarga.

Covid-19 menyebabkan kegiatan pembelajaran dilaksanakan dari rumah, secara online dan dengan jarak jauh. Kondisi ini yang menyebabkan terbatasnya interaksi peserta didik dengan lingkungan sosial terutama teman sebayanya. Minimnya interaksi ini yang menyebabkan peranan teman sebaya tidak berpengaruh signifikan terhadap hasil belajar. Di dukung pula dengan penelitian (Agustina and Kurniawan 2020) yang menyebutkan bahwa lingkungan keluarga berpengaruh besar terhadap motivasi belajar sehingga didapatkan hasil bahwa peranan teman sebaya tidak berpengaruh terhadap hasil belajar melalui motivasi belajar. Terlepas dari motivasi belajar masih ada faktor internal lain yang dapat menjadi variabel intervening antara teman sebaya terhadap hasil belajar yang tidak diteliti oleh peneliti pada penelitian ini.

Dengan demikian, dalam kondisi pandemi covid-19 dengan pembelajaran yang dilakukan secara daring motivasi belajar tidak dapat menjadi variabel intervening peranan teman sebaya terhadap hasil belajar yang diperoleh peserta didik kelas XI IPS di SMAN 2 Tuban.

\section{Pengaruh Kebiasaan Belajar pada Masa Pandemi Covid-19 terhadap Hasil Belajar dengan Motivasi Belajar sebagai Variabel Intervening}

Hasil yang diperoleh dari pengujian hipotesis kebiasaan belajar di masa pandemi covid-19 terhadap hasil belajar ekonomi dengan motivasi belajar sebagai variabel intervening memiliki koefisien jalur sebesar 0,241 dan $p$-value sebesar $<0,001$. Mengingat $p$-value $<0,05$ maka dikatakan signifikan. Diketahui bahwa 
motivasi belajar dapat menjadi variabel intervening kebiasaan belajar terhadap hasil belajar sehingga hipotesis diterima.

Data empiris dilapangan menunjukkan peserta didik yang berkebiasaan belajar baik dan termotivasi belajar, memperoleh hasil belajar yang tinggi. Begitupun kebalikannya, peserta didik yang berkebiasaan belajar buruk dan kurang termotivasi untuk belajar, memperoleh hasil belajar yang rendah.

Penelitian yang memperkuat hasil tersebut adalah penelitian yang dilakukan oleh (Hasanah et al. 2016; Prihatmoko 2013; Wulandari 2020) yang menyebutkan kebiasaan belajar berdampak signifikan pada motivasi belajar. Kebiasaan belajar peserta didik memberikan dampak positif pada motivasi belajarnya yang mana nantinya akan membuat peserta didik turut aktif dalam aktivitas belajar atas dorongan pribadi (tidak ada paksaan dari orang lain). Motivasi atau dorongan inilah yang menjadikan peserta didik untuk terus belajar hingga membentuk sebuah kebiasaan.

Indikator peserta didik mempunyai kebiasaan belajar yang baik ialah memiliki waktu belajar yang rutin setiap harinya, berkonsentrasi penuh saat belajar, serta mempersiapkan diri dengan membaca materi sebelum pelajaran. Dengan demikian hasil belajar merupakan cerminan dari kebiasaan belajar peserta didik. Hal ini didukung dengan penelitian (Salcedo-Relucio 2019) yang mengemukakan kebiasaan belajar mengambil peran penting dalam kehidupan peserta didik dan berpengaruh pada keberhasilan belajarnya.

Dengan demikian, dalam kondisi pandemi covid-19 dengan pembelajaran yang dilakukan secara daring motivasi belajar dapat menjadi variabel intervening kebiasaan belajar terhadap hasil belajar ekonomi yang diperoleh peserta didik kelas XI IPS di SMAN 2 Tuban.

Keterbatasan penelitian ini adalah hanya dibatasi atas 3 faktor yang berpengaruh terhadap hasil belajar, yaitu: (1) Peranan teman sebaya; (2) Kebiasaan belajar; (3) Motivasi belajar. Penelitian ini dikhususkan untuk hasil belajar mata pelajaran ekonomi pada peserta didik kelas XI IPS SMAN 2 Tuban Tahun Ajaran 2020/2021.

\section{KESIMPULAN}

Berdasar temuan penelitian yang dilakukan di SMAN 2 Tuban kelas XI IPS pada masa pandemi covid19 dengan pembelajaran berbasis daring didapatkan kontribusi implikasi secara teoritis diantaranya teman sebaya dengan semangat belajar tinggi turut berperan memotivasi belajar individu lain, peserta didik dengan kebiasaan belajar yang baik diartikan memiliki motivasi belajar yang tinggi, memiliki teman dengan nilai yang baik pada mata pelajaran ekonomi tidak berpengaruh terhadap perolehan nilai individu lain dalam kelompok, peserta didik dengan kebiasaan belajar yang baik memperoleh hasil belajar yang tinggi, motivasi belajar tidak mempu menjadi perantara teman sebaya terhadap hasil belajar, dan motivasi belajar mampu menjadi perantara kebiasaan belajar terhadap hasil belajar sehingga diketahui bahwa aspek yang memengaruhi hasil belajar adalah motivasi belajar dan kebiasaan belajar. Dan aspek yang mempengaruhi motivasi belajar diantaranya peranan teman sebaya dan kebiasaan belajar. Dengan demikian dapat disarankan agar peserta didik hendaknya menjaga lingkungan pertemanan. Teman bergaul yang memiliki semangat tinggi dalam belajar dapat berpengaruh baik terhadap motivasi belajar. Peserta didik hendaknya dapat secara mandiri memperhatikan kebiasaan belajar pada masa pembelajaran daring, kebiasaan belajar yang baik akan berdampak pada motivasi belajar dan hasil belajar

\section{DAFTAR PUSTAKA}

Agustina, Menik Tetha and Danang Afi Kurniawan. 2020. "Motivasi Belajar Mahasiswa Di Masa Pandemi Covid-19.” Jurnal Psikologi Perseptual 5(2):120.

Alyaum, Nabhan Mudrik. 2020. "Riset: Pelajar Merasa Belajar Di Rumah Tidak Efektif.” Ibtimes.Id 1. 
Retrieved (https://ibtimes.id/riset-pelajar-merasa-belajar-di-rumah-tidak-efektif/).

Bakar, Ramli. 2014. THE EFFECT OF LEARNING MOTIVATION ON STUDENT'S PRODUCTIVE COMPETENCIES IN VOCATIONAL HIGH SCHOOL, WEST SUMATRA.

Cahyani, Adhetya, Iin Diah Listiana, and Sari Puteri Deta Larasati. 2020. "Motivasi Belajar Siswa SMA Pada Pembelajaran Daring Di Masa Pandemi Covid-19." IQ (Ilmu Al-Qur'an): Jurnal Pendidikan Islam 3(01):123-40.

Chamundeswari, S., V. Sridevi, and Archana Kumari. 2014. "Self-Concept, Study Habit and Academic Achievement of Students." International Journal of Humanities Social Sciences and Education 1(10):47-55.

Dörnyei, Zoltán and Ema Ushioda. 2013. Teaching and Researching Motivation, Second Edition.

Fitriyani, Yani, Irfan Fauzi, and Mia Zultrianti Sari. 2020. "Motivasi Belajar Mahasiswa Pada Pembelajaran Daring Selama Pandemik Covid-19.” Profesi Pendidikan Dasar 7(1):121-32.

Fouché, J. P. 2017. "The Reported Study Habits and Time-Management Trends of Post-Graduate Students in Accountancy." South African Journal of Higher Education 31(6).

Ghozali, I. and H. Latan. 2014. Partial Least Squares Konsep, Metode Dan Aplikasi Menggunakan Program WarpPLS 4.0. Third. edited by B. P. U. Diponegoro. Semarang.

Guay, Frédéric, Julien Chanal, Catherine F. Ratelle, Herbert Marsh, Simon Larose, and Michel Boivin. 2010. "Intrinsic, Identified, and Controlled Types of Motivation for School Subjects in Young Elementary School Children." British Journal of Educational Psychology.

Hartini, Sri. 2020. "Dampak Pembelajaran Daring Terhadap Hasil Belajar Mahasiswa Intitut Pendidikan Tapanuli Selatan Masa Pandemi Covid-19.” 8(4):413-14.

Hasanah, S., O. Abdurakhman, and M. Ichsan. 2016. "Pengaruh Kebiasaan Belajar Terhadap Motivasi Belajar Siswa Study Habits Influence Motivation towards Learning Students." 44-47.

Hassan, Uzma, Shazia Sadaf, Syed Moyn Aly, and Lubna Ansari Baig. 2018. "Study Habits;" The Professional Medical Journal 25(03):466-72.

Jatira, Yadi and S. Neviyarni. 2021. "Fenomena Stress Dan Pembiasaan Belajar Daring Dimasa Pandemi Covid-19." Edukatif: Jurnal Ilmu Pendidikan 3(1):35-43.

Lestari, Alia, Nur Ma'wiyah, and Muhammad Ihsan. 2020. "Kontribusi Dukungan Keluarga Dan Teman Bergaul Terhadap Indeks Prestasi Kumulatif Mahasiswa Dengan Memperhatikan Intensitas Belajar.” AlKhwarizmi: Jurnal Pendidikan Matematika Dan Ilmu Pengetahuan Alam 8(1):51-60.

Menteri Pendidikan dan Kebudayaan. 2020. PELAKSANAAN KEBIJAKAN PENDIDIKAN DALAM MASA DARURAT PENYEBARAN CORONAVIRUS DISEASE (COVID-19). Indonesia.

Novandhika, Atiko Putra. 2017. "HUBUNGAN ANTARA KOMITMEN PERSAHABATAN DENGAN PEMAAFAN PADA REMAJA."

Pratama, Frandy, Firman, and Neviyarni. 2019. "Pengaruh Motivasi Belajar IPA Siswa Terhadap Hasil Belajar.” Jurnal Ilmu Pendidikan 1(3):280-86.

Prihatmoko, Pebri. 2013. "PENGARUH KEBIASAAN BELAJAR DAN FASILITAS BELAJAR TERHADAP MOTIVASI BELAJAR SISWA KELAS X DAN XI DI SMK TAMAN SISWA JETIS YOGYAKARTAJURUSAN TEKNIK KOMPUTERDAN JARINGAN.” Universitas Negeri Yogyakarta.

Puspensos. 2020. "Dinamika Pembelajaran Jarak Jauh Di Era Pandemi COVID-19." Puspensos.Kemsos.Go.Id. Retrieved (https://puspensos.kemsos.go.id/dinamika-pembelajaran-jarak-jauhdi-era-pandemi-covid-19).

Rabia, Mahwish, Naima Mubarak, Hira Tallat, and Wajiha Nasir. 2017. "A Study on Study Habits and 
805 Peranan Teman Sebaya dan Kebiasaan Belajar terhadap Hasil Belajar Melalui Motivasi Belajar di Masa Covid-19 - Puput Agustiningtyas, Jun Surjanti

DOI: https://doi.org/10.31004/edukatif.v3i3.454

Academic Performance of Students." International Journal of Asian Social Science 7(10):891-97.

Salcedo-Relucio, Maria Angelica. 2019. "Factors Affecting the Study Habits of Grade Eleven Students in One National High School in Pangasinan, Philippines." Southeast Asian Journal of Science and Technology 4(1):89-97.

Santrock, John W. 2011. "Educational Psychology 5th Edition.” Educational Psychology.

Sardiman. 2012. Model Interaksi Dan Motivasi Belajar Mengajar. Jakarta: Rajawali Press.

Sartika, Sri Hardianti, Dadang Dahlan, and Ikaputra Waspada. 2018. "Kompetensi Guru Dan Motivasi Belajar Siswa Terhadap Hasil Belajar Melalui Kebiasaan Belajar Siswa." Jurnal MANAJERIAL 17(1):39.

Sholihah, Amilatus and Riza Yonisa Kurniawan. 2016. "Analisis Pengaruh Motivasi Belajar Dan Lingkungan Belajar Terhadap Hasil Belajar.” Jurnal Pendidikan Ekonomi (JUPE) 4(3).

Suprijono, Agus. 2014. Cooperative Learning. Yogyakarta: Pustaka Pelajar.

Wilson, Dan. 2016. "Partinership for Learning: Peer Group Influences on Learning Outcomes.” 2.

Wulandari, Jumairoh Indah. 2020. "PENGARUH PENGGUNAAN GADGET DAN KEBIASAAN BELAJAR TERHADAP MOTIVASI BELAJAR SISWA KELAS V SD NEGERI DABIN VI KECAMATAN KETANGGUNGAN KABUPATEN BREBES.”Universitas Negeri Semarang. 